\title{
ENTRE EL DEBER Y LA DEFENSA DEL PRIVILEGIO. NOBLEZA Y EXENCIÓN FISCAL EN ANDALUCÍA (CA. S. XV-PRINCIPIOS DEL XVI)*
}

\author{
Among the duty and the defense of the privilege. \\ Nobility and tax exention in Andalucia (15th-16th centuries)
}

JOSÉ MANUEL TRIANO MILÁN**

Recibido: 27-01-2018

Aprobado: 03-11-2020

\section{RESUMEN}

En el presente artículo analizamos la obligación que tuvo la nobleza andaluza de participar en algunas contribuciones extraordinarias de la Corona y el pago de ciertos impuestos municipales. Aspecto que fue consecuencia directa de la situación fronteriza de este territorio y las urgencias que generaba su defensa. Ello tuvo un impacto que trascendió con mucho el campo meramente económico, incidiendo en la relación de este estamento con la Corona y los poderes municipales y marcando la forma de entender algunas de las principales características que definían su condición social.

Palabras clave: Fiscalidad extraordinaria; Corona de Castilla; nobleza; privilegio.

\section{ABSTRACT}

In this article we analyze the payment of the Andalusian nobility of certain royal and council extraordinary taxes. A direct result of the border condition of this space and the urgencies generated by its defense. This had an impact that far transcended the purely economic field, affecting the relationship of this estate with the Crown and the municipal powers and marking the way to understand some of the main characteristics that defined their social status.

Keywords: Extraordinary taxation; Crown of Castile; nobility; privilege.

Contesció que algunos baxos e pobres omes fesieron algunos buenos e nobles fechos de armas [...] por lo qual [...] dieron riquezas e faziendas e quisieron que fueran librados y exemptos de todos tributos e pechos, e donde en adelante los ouieron por fidalgos e nobles. Rodrigo SÁnchez de ArÉvalo. Vergel de príncipes

* El presente trabajo se ha sido financiado por los proyectos de investigación "La construcción de una cultura fiscal en Castilla: poderes, negociación y articulación social (ca. 1250-1550)" (PGC2018-097738-B-100) y "De la lucha de Bandos a la hidalguía universal: transformaciones sociales, políticas e ideológicas en el País Vasco (siglos XIV-XVI)" (HAR2017-83980-P) del Ministerio de Ciencia, Innovación y Universidades. Así mismo, cuenta con el sostén del Proyecto de Generación de Conocimiento Frontera del Plan Andaluz de Investigación, Desarrollo e Innovación "Circuitos financieros, crecimiento económico y guerra (siglos XV-XVI)" (UMA18-FEDERJA-098) de la Junta de Andalucía y el Grupo Consolidado de Investigación del Gobierno Vasco "Sociedad, poder y cultura (siglos XIV-XVIII)" (IT-896-16). Todos ellos forman parte de la Red de investigación cooperativa Arca Comunis (www.arcacomunis.uma.es).

** Universidad del País Vasco. josemanuel.triano@ehu.us 


\section{INTRODUCCIÓN: ESTATUS, NOBLEZA Y EXENCIÓN FISCAL}

La exención fiscal ha venido siendo considerada tradicionalmente como uno de los principales elementos de distinción en las sociedades bajomedievales y modernas $^{1}$. Y es que estar eximido de ciertas cargas tributarias suponía más que una mera ventaja económica, era una muestra de posición social ${ }^{2}$. No obstante, dicha condición no supuso nunca una clara línea separadora entre los grupos privilegiados (nobleza y clero) y aquellos que no lo eran, como ha venido a defender, de manera un tanto simplista, cierta historiografía ${ }^{3}$. En la práctica, los límites de estos estamentos eran sumamente difusos, dada la indefinición jurídica que los caracterizó a lo largo de todo este período ${ }^{4}$. Algo que se reflejaba en las honras, franquezas, libertades y exenciones de las que disfrutaron sus miembros. Estas no fueron nunca homogéneas, presentando sensibles diferencias aún dentro del propio estamento, reflejando cierta jerarquización interna ${ }^{5}$. Los

1. Ya la propia calificación de pechero hacía referencia a la condición de contribuyente del individuo. En torno a la importancia de la exención fiscal como elemento de distinción social de la nobleza véase Marie Claude Gerbet, La nobleza en la Corona de Castilla. Sus estructuras sociales en Extremadura (1454-1516) (Diputación provincial de Cáceres: Cáceres, 1989), 49; Idem,"Les guerres et l'accès à la noblesse en Espagne de 1465-1592", Mélanges de la Casa Velázquez, VII (1972): 307-309 y Rafael Sánchez Saus, Caballería y linaje en la Sevilla Medieval. (Cádiz: Diputación provincial de Sevilla y Universidad de Cádiz, 1989), 31.

2. María Isabel del Val Valdivieso, "Oligarquía versus común. Consecuencias sociopolíticas del triunfo del regimiento en las sociedades castellanas", Medievalismo, no 4 (1994): 49-52 y Raúl González González, "La exención fiscal, entre el privilegio y el conflicto: los excusados de la Iglesia en Astorga, León y Oviedo", Historia. Instituciones. Documentos, no 42 (2015): 158. En ocasiones estas exenciones presentan otro cariz: el de la defensa a grupos particularmente desprotegidos de la sociedad. Es el caso de aquellos individuos que por no alcanzar una cantidad mínima en la cuantificación de la riqueza eran considerados pobres fiscales y, por tanto, no participaban en ciertas contribuciones directas (pedidos, empréstitos). Sin embargo, esta condición podía resultar sumamente variable, tal y como hemos podido constatar en la ciudad de Sevilla en el siglo XV, ya que las autoridades municipales contaron con la capacidad de modificar las cáñamas según sus intereses recaudatorios, aumentando o estrechando el cuerpo de contribuyentes según sus intereses. José Manuel Triano Milán, La llamada del rey y el socorro del reino. Del pedido regio a las contribuciones de la Santa Hermandad (1476-1498) (Sevilla: Universidad de Sevilla, 2018), 153.

3. Como ha puesto de relieve el profesor Antonio Collantes de Terán Sánchez, "Los sevillanos ante el impuesto: la exención fiscal (siglos XIII-XVI)", Minervae Baeticae, no 41 (2013): 293. Que las franquezas no podían ser simplemente identificadas con la condición de nobleza o hidalguía fue puesto de relieve ya por algunos tratadistas castellanos. Sobre esta cuestión Alfonso de Otazu y José Ramón Díaz de Durana, El espíritu emprendedor de los vascos (Madrid: Sílex, 2008), 82.

4. Antonio Domínguez Ortiz, Las clases privilegiadas en el Antiguo Régimen (Madrid: Akal, 2012), 28 y ss. y Enrique Soria Mesa, La nobleza en la España moderna. Cambio y continuidad (Madrid: Marcial Pons, 2007), 37.

5. Domínguez Ortiz, Las clases privilegiadas, 47 y ss. y Soria Mesa, La nobleza en la España moderna, 37 y ss. No obstante, en el caso de la nobleza esta jerarquización fue una realidad borrosa hasta comienzos del siglo XVI.

Chronica Nova, 46, 2020, 407-433 - http://doi.org/10.30827/cnova.v0i46.6797 
privilegios fiscales tampoco eran, en modo alguno, una característica privativa de la nobleza y el clero. Existió un amplio abanico de grupos sociales y profesionales que, pese a no pertenecer stricto sensu al ámbito de los estamentos privilegiados ni a sus clientelas, gozaron de exenciones o franquezas más o menos amplias, en ocasiones incluso superiores a las de aquellos ${ }^{6}$. Por tanto, pese a ser un indicador útil a la hora de definir el estatus de un individuo o grupo social, la exención fiscal no marcaba la pertenencia a estos estamentos de manera unívoca? ${ }^{7}$.

Estos privilegios fiscales fueron, además, una realidad sumamente cambiante. Pese al estatismo que trató de presentar la literatura destinada a justificar la preeminencia de nobleza y clero ${ }^{8}$, lo cierto es que las prerrogativas de las que gozaron estuvieron en permanente conflicto y transformación ${ }^{9}$. En una sociedad marcada por la competencia por las oportunidades de estatus y prestigio, la pretensión ya no solo de mantener dichos privilegios para su disfrute y el de sus descendientes — en el caso de la nobleza_, sino el ampliarlos por vías más o menos legítimas, fue una constante aspiración. Aspiración que chocó directamente con otros grupos sociales que deseaban alcanzar las mismas condiciones o se consideraban agraviados por ellas. También se generaron importantes tensiones con las autoridades de los emergentes sistemas fiscales estatales y concejiles, que pretendieron limitar estas franquezas y lograr una mayor participación contributiva de estos grupos esgrimiendo el concepto de bien común ${ }^{10}$. Así, las ventajas fiscales

6. Así, por ejemplo, desde un punto de vista fiscal algunos de los grupos francos establecidos en Sevilla podían ser considerados superiores a la nobleza. Estos, además, gozaban de otras ventajas, como jurisdicciones especiales o el descargo de servicios militares. Antonio Collantes de Terán Sánchez, Sevilla en la Baja Edad Media. La ciudad y sus hombres (Sevilla: Ayuntamiento de Sevilla, 1984), 233-234.

7. No obstante, este hecho era utilizado habitualmente por muchos como un trampolín para la promoción social. Así, gracias a ella era más sencillo acceder a la hidalguía u otras capas de la nobleza. Algunos autores han señalado, incluso, cómo una eventual exención podría suponer la entrada en la nobleza de facto. Gerbet, "Les guerres et l'accès à la noblesse", 307.

8. El profesor Soria Mesa ha venido a hablar de cambio inmóvil, una expresión que refleja ese dualismo entre la pretensión de permanencia que mostraban estos grupos y el inevitable cambio social al que se vieron sometidos. Soria Mesa, La nobleza en la España moderna, 16-17 y Enrique Soria Mesa, El cambio inmóvil. Transformaciones y permanencias en una élite de poder (Córdoba, ss. XVI-XIX) (Córdoba: Ayuntamiento de Córdoba, 2000), especialmente en las páginas 13-16.

9. Luis Díaz de la Guardia y López, "Exención fiscal nobiliaria en el ámbito local bajomedieval. En torno a tres documentos de la villa de Belmonte", Espacio, Tiempo y Forma, Serie III, Historia Medieval, t. 19 (2007):138-147 e Idem, "Los pleitos plenos de hidalguía en la Baja Edad Media: una posible evolución jurídica bajo los Trastámaras desde la óptica de la Edad Moderna", Espacio, Tiempo y Forma, Serie III, Historia Medieval, t. 21 (2008): 51.

10. Un claro ejemplo de ello en las contribuciones de la Santa Hermandad en José Manuel Triano Milán, "De la restauración de la justicia a la lucha contra el infiel. La legitimación de los ingresos fiscales de la Santa Hermandad (1476-1498)". En la España Medieval, nº 41 (2018): 113. 
de estos estamentos fueron tomando forma al calor de una relación dialéctica con otros grupos sociales y poderes políticos en un marco legal sumamente complejo, marcado por la presencia de múltiples ordenamientos jurídicos.

En el caso de la nobleza este proceso cobró un nivel de complejidad mayor como resultado del debate que se generó en los siglos finales del medievo sobre el origen de su situación de privilegio y las funciones que le eran propias. El proceso de reforzamiento de la autoridad de príncipes y monarcas y su deseo de ampliar su jurisdicción frente a otros cuerpos políticos llevó a que se cuestionara la tradicional visión que se había tenido sobre este asunto. Junto a la consideración de la nobleza sustentada en la sangre fue cobrando fuerza la concepción de una nobleza de tipo civil, que dependía directamente de la designación del príncipe. Este habría de convertirse en la autoridad competente a la hora de dirimir quién era noble y quién no. Para ello se procedió a promulgar y aplicar nuevas normas fiscales, militares y jurídicas, que fueron alcanzando un grado de definición cada vez mayor ${ }^{11}$. Proceso que no se llevó a cabo sin cierta contestación, tal y como se refleja en la abundante tratadística de la época ${ }^{12}$.

En el territorio andaluz la conflictividad originada por todas estas cuestiones fue especialmente intensa, potenciada por algunas particularidades propias de la región. Allí, la condición fronteriza del espacio favoreció que uno de estos estamentos, la nobleza, mantuviera una relación con el hecho fiscal un tanto diferente al que tenía en el resto de la Corona. Los nobles andaluces se vieron en la disyuntiva entre cumplir con el deber que habían contraído como defensores de la sociedad o proteger sus privilegios ${ }^{13}$. Esta dicotomía marcó profun-

11. Joseph Morsel, La aristocracia medieval. El dominio social en Occidente (siglos V-XV) (Valencia: Universidad de Valencia, 2008), 356-357.

12. Así ocurrió en Castilla, donde frente a encarecidos defensores de la capacidad del príncipe para designar a la nobleza, caso de Diego de Valera, se alzaron aquellos que defendían que esta condición solo procedía del linaje, como ocurrió con Bartolomé de Mexía. Domingo Centenero de Arce, "De lo cuantitativo a lo cualitativo. Los pleitos de hidalguía y la tratadística jurídica". Obradoiro de Historia Moderna, $\mathrm{n}^{\circ} 24$ (2015): 303-304.

13. La concepción de que estos privilegios eran la contraprestación que la sociedad otorgaba a la nobleza por su labor defensiva fue defendido por algunos importantes tratadistas del período, como Rodrigo Sánchez de Arévalo en el texto que preside estas páginas. Rodrigo Sánchez de Arévalo, "Vergel de príncipes", en Prosistas castellanos del siglo XV, ed. Mario Penna. (Madrid: Biblioteca de Autores Españoles, Atlas, 1959), 371. Un interesante estudio de estos discursos legitimadores de la nobleza castellana en María Concepción Quintanilla Raso, "La nobleza", en Orígenes de la Monarquía Hispánica. Propaganda y legitimación (ca. 1400-1520), dir. José Manuel Nieto Soria (Madrid: Dykinson, 1999), 73-86. Ya para época moderna véase a José Antonio Guillén Berrendero, "La tratadística nobiliaria como espejo de nobles. El ejemplo de Juan Benito Guardiola y su tratado de nobleza de 1591", Brocar: cuadernos de investigación histórica, no 26 (2002): 81-106 y "El reconociendo a los nobles y católicos castellanos en tiempos de Santa Teresa de Jesús. Una reflexión sobre la tratadística nobiliaria y la presencia de la devoción", eHumanista: Journal of Iberian Studies, vol. 33 (2016): 191-211.

Chronica Nova, 46, 2020, 407-433 - http://doi.org/10.30827/cnova.v0i46.6797 
damente sus relaciones con las autoridades de la Real Hacienda y los concejos, así como en la forma de entender algunos de los aspectos más representativos de su condición social.

\section{"POR EL BIEN COMÚN E DEFENSIÓN DE AQUELLA TIERRA". LA PARTICIPACIÓN FISCAL DE LA NOBLEZA ANDALUZA Y SU IMPACTO ECONÓMICO Y SOCIAL (1406-1478)}

Como ya hemos señalado, la relación de la nobleza andaluza con el sistema fiscal estatal y el de las diversas haciendas municipales difirió sensiblemente del de otras áreas de la Corona como consecuencia de las particularidades jurídicas del territorio en el que se asentaba. En las regiones más fronterizas los nobles se beneficiaron, al igual que el resto de vecinos, de las amplias exenciones que los monarcas concedieron para evitar el despoblamiento de unas villas y ciudades siempre amenazadas por la cercanía de las fuerzas musulmanas ${ }^{14}$. Estas gozaron de una situación sumamente ventajosa, siendo eximidas de numerosas cargas tributarias que solo empezarían a ser demandadas tras la caída de Granada en manos castellanas ${ }^{15}$. En los espacios que quedaron un tanto más rezagados de la Banda Morisca se estableció una clara dualidad. Los territorios de señorío mantuvieron una relación claramente privilegiada con la Real Hacienda, siendo eximidos de numerosas cargas y registrando una presión fiscal mucho menor cuando hubieron de pagar. Por su parte, aquellos pecheros que se encontraban bajo jurisdicción real hubieron de experimentar una carga contributiva mucho mayor. Estos niveles de contribución y la solidez de las aportaciones evidencian un nivel de autoridad fiscal por parte de la hacienda estatal y las haciendas municipales en el territorio de realengo andaluz muy superior al que se aplicaba en otras partes de Castilla ${ }^{16}$. Tanto es así, que allí dicha autoridad se pudo hacer extensiva, incluso, al estamento nobiliario. Desde el más humilde de los hidalgos

14. Estas exenciones son uno de los elementos más representativos de ese "derecho de frontera" del que han venido a hablar algunos especialistas. Manuel González Jiménez, "Poblamiento y frontera en Andalucía (ss. XIII-XV)", Espacio, Tiempo y Forma, Serie III, Historia Medieval, t. 4 (1989): 212-213. José Manuel Triano Milán, "El arzobispado de Sevilla y el obispado de Cádiz. Imagen de un gran partido fiscal en la recaudación del pedido regio", Historia. Instituciones. Documentos, ${ }^{\circ}$ 40 (2013): 379-381.

15. Es el caso de lo ocurrido en la ciudad de Antequera, donde vemos como este cambio en la situación fiscal de la plaza se ve acompañado por una intensa resistencia por parte de las élites concejiles para sustraerse al pago de los servicios extraordinarios de la Corona. ARCHGR, Pleitos, Caja 780, Pieza 4 y Caja 2895, Pieza 15.

16. Sobre este asunto véase Juan Manuel Carretero Zamora, La averiguación de la Corona de Castilla, 1525-1540. Los pecheros y el dinero del reino en época de Carlos V. Tomo I (Valladolid: Junta de Castilla y León, 2008), 21-36 y Triano, La llamada del rey, 107 y ss. 
hasta el más poderoso de los ricoshombres se vieron obligados a contribuir en algunos de los ingresos extraordinarios demandados por la Corona (pedidos, empréstitos, repartimientos militares) así como en diversos impuestos concejiles ${ }^{17}$. Al mismo tiempo, se impidió a estos individuos eximir a ciertas personas bajo su protección - los denominados apaniaguados - , práctica sumamente habitual en otros espacios, tal como reflejan las constantes menciones a esta cuestión en las Actas de Cortes a lo largo de toda la centuria ${ }^{18}$.

Esta situación, que ha venido a ser designada por algunos especialistas como "fuero de Andalucía", encontró clara expresión en algunos textos normativos como las Actas de las Cortes de Valladolid de $1451^{19}$ :

[...] los quales biben en Andaluzia donde todos común mente pechan asi ricos omes commo caualleros fijos dalgo e otros quales quier, lo qual se acostumbró siempre asi fazer por el bien común e defensión de aquella tierra e todos pechen e paguen los pechos reales e conçejales ${ }^{20}$.

Su legitimación se sostuvo sobre la imperiosa necesidad de defensa del territorio andaluz, siempre bajo la teórica amenaza del reino nazarí de Granada. Aunque los nobles participaban ya en dicha defensa mediante el ejercicio de las armas $-\mathrm{y}$ el consiguiente esfuerzo financiero que ello suponía ${ }^{21}$ - se creyó necesario también un sacrificio complementario de carácter económico. Curiosamente, el argumento sobre el que tradicionalmente se había sustentado su privilegiada condición pasaba a convertirse ahora en la excusa para hacerlos partícipes del sostenimiento de las emergentes estructuras hacendísticas de los concejos y del Estado. A este razonamiento vino a unirse el de que resultaba

17. No obstante, los nobles andaluces gozaban de exención de la otra vía del servicio de Cortes, las monedas, y otros impuestos reales, así como buena parte de los pechos que se demandaban a nivel local. Collantes de Terán, "Los sevillanos ante el impuesto", 309-310.

18. Cortes, Tomo III, 104-115, 218-220, 247-248 y 652-653 (Cortes de Palencia de 1431, Disposición 19; Cortes de Madrid de 1435, Disposiciones 26 y 46 y Cortes de Burgos de 1453, Disposición 4).

19. No es la única referencia que contamos en torno a esta cuestión, que es un lugar común en la documentación conservada a nivel municipal. Así, en la carta del pedido de 1408 a la ciudad de Sevilla se insiste en que "esta çibdad e las villas e lugares de la dicha su tierra se poblo so este fuero que los maestres e condes e ricos omes e caualleros e escuderos e fijosdalgo e todas las personas seglares pagasen en los pechos concejales segund que es el dicho pedido e en otros semejantes deste. E asy se a usado y guardado fasta agora". AMS, Pap. May., Año 1408.

20. Cortes, Tomo III, 630 (Disposición 40 de las Cortes de Valladolid de 1451).

21. Una crítica en este sentido lo encontramos en el pleito que mantuvo Diego García de Zalamea con el concejo de Don Benito a fines del siglo XV por hacerlo participar en unos repartimientos, lesionando no solo su exención como caballero sino olvidando los grandes gastos y sacrificios económicos y personales que había hecho en la Guerra de Granada. ARCHGR, Pleitos, Caja 2833, Pieza 5. 
imprescindible que estos grupos asumieran parte de la carga fiscal, limitando el peso que habrían de asumir el resto de pecheros ${ }^{22}$.

Esta particular relación de la nobleza andaluza con el hecho fiscal, sin embargo, no fue tan homogénea como la normativa podría hacernos creer. Las disposiciones generales contrastan con una realidad que, tal y como muestra la documentación de carácter local, vino a diferir sensiblemente incluso entre concejos cercanos entre sí $^{23}$. Situación que parece que tuvo mucho que ver con la creciente capacidad de decisión en materia fiscal que les fue cediendo la Corona en lo relativo a alguno de sus ingresos extraordinarios. Esto es, la aplicación de esta disposición vino a convertirse en una decisión de carácter municipal ${ }^{24}$.

La relevancia de la suspensión de algunas de las exenciones fiscales de la nobleza no fue similar para los distintos grupos que componían el estamento nobiliario ni su efecto fue el mismo desde todos los puntos de vista. En lo relativo a su impacto económico, parece que la contribución a las demandas directas de la fiscalidad extraordinaria de la Corona y los concejos fue, por lo general, percibida como una las cargas fiscales más gravosas que hubieron de afrontar ${ }^{25}$. No obstante, cabe suponer que para los grupos más pudientes de la nobleza andaluza hacer frente a este tipo de peticiones no hubo de suponer un esfuerzo excesivo, vista su elevada capacidad adquisitiva y el carácter limitado de estas demandas ${ }^{26}$. Menos aún si tenemos en cuenta que en los ámbitos urbanos estos, por lo general, encontraron formas de contribuir que resultaban significativamente más livianas de las que teóricamente habrían tenido que soportar

22. Triano, La llamada del rey, 380.

23. Sobre este aspecto llamaron la atención las profesoras María Concepción Quintanilla Raso y María Asenjo González, "Los hidalgos en la sociedad andaluza a fines de la Edad Media", en Las ciudades andaluzas (siglos XIII-XVI). Actas del VI Coloquio Internacional de Historia Medieval de Andalucía, ed. José Enrique López de Coca Castañer y Ángel Galán Sánchez (Málaga: Universidad de Málaga, 1991), 424.

24. José Manuel Triano Milán, “¿Un nuevo sistema de fiscalidad extraordinaria? La Santa Hermandad de los Reyes Católicos (1476-1498)", Studia Histórica. Historia Medieval, n 36/2 (2018): 177 y ss.

25. Seguramente como resultado de su carácter directo. Algunas menciones a lo gravosas que resultaban este tipo de demandas en Cortes, Tomo III, 80-82 (Cortes de Burgos de 1430, Disposición 3 y 5) y 422-424 (Cortes de Valladolid de 1442, Disposición 23). Sobre cómo las contribuciones directas eran consideradas habitualmente más gravosas que las de tipo indirecto Juan Manuel Carretero Zamora, "Los concejos castellanos y el regimen señorial ante la Real Hacienda. La gestión de los servicios (1500-1556)", en Tesoreros, arrendadores y financieros en los reinos hispánicos: la Corona de Castilla y el reino de Navarra (siglos XIV-XVII), ed. Ernesto García Fernández (Madrid: Instituto de Estudios Fiscales y Universidad de Málaga, 2012), 203.

26. Una imagen del potencial económico de este grupo en el caso de la ciudad de Sevilla en Collantes de Terán, Sevilla en la Baja Edad Media, 285-291. Parece que las contribuciones extraordinarias de la Corona nunca superaron los 4.000 maravedís por pechero, tal y como se refleja en las hojas de repartimiento y los padrones de la ciudad de Sevilla. 
dada la relevancia de sus haciendas. Sin embargo, para aquellos sectores con menor capacidad adquisitiva dentro de la nobleza estas demandas sí que pudieron suponer cierto quebranto a sus haciendas, especialmente en unos espacios rurales en los que no era tan sencillo adherirse a mecanismos de pago favorables a sus intereses. No es de extrañar, por tanto, que muchos de estos individuos buscaran vías alternativas para librarse de este tipo de contribuciones, recurriendo habitualmente al fraude o dando lugar a algunas de las más enérgicas actitudes de resistencia a la contribución que podemos encontrar en los testimonios de la época, como tendremos ocasión de tratar.

Como señalábamos anteriormente, uno de los principales objetivos de este esfuerzo era que la nobleza asumiera parte de la carga que habían de soportar los pecheros. Pero cabe plantearse qué parte de las contribuciones totales demandadas vino a asumir este estamento en la práctica y hasta qué punto ello supuso un alivio para el resto de contribuyentes. Desafortunadamente, no resulta sencillo responder a estas preguntas, ya que la documentación en torno a las aportaciones fiscales de la nobleza resulta sumamente fragmentaria y dispersa. Pese a la obligación existente por normativa para que en los padrones de tasación y repartimiento se asentara a cada contribuyente con su correspondiente condición, lo cierto es que esta práctica no fue habitual, lo que impide rastrear la valoración de la riqueza y la aportación fiscal resultante de este estamento ${ }^{27}$. Tampoco hemos localizado de momento otros documentos que contemplen esta información en detalle, por lo que únicamente podremos aproximarnos a este problema a través de una serie de testimonios un tanto indirectos. Es el caso de la información contenida en una documentación sumamente interesante y poco puesta en valor hasta ahora: las hojas de repartimiento en el pedido regio de los regidores y los ricoshombres de la ciudad de Sevilla ${ }^{28}$.

27. "[...] E que empadronara por calles a todas las personas que ouiere en el lugar poniendo en ellas al contioso e al que no ouiere contía por no contioso e al hidalgo por hidalgo e al clérigo por clérigo e al pechero por pechero [...]". AMJF, Act. Cap., Año 1447, f. 36 r. Un simple vistazo a los abundantes padrones conservados en la sección Diversos del Archivo Municipal Hispalense permite observar lo habitual que resultaba el incumplimiento de la norma.

28. Sobre este tipo de documentación, su significación y sus posibilidades para la investigación véase Julieta Rodríguez Sarria, "Fisco, poder y distinción social en Sevilla y su tierra en el siglo XV: una propuesta de trabajo", en Poder, fisco y mercado en las ciudades de la Península Ibérica (siglos XIV-XVI), ed. David Carvajal de la Vega, Imanol Vítores Casado y Javier Añibarro Rodríguez (Valladolid: Castilla ediciones, 2016) y Triano, La llamada del rey, 262-265.

Chronica Nova, 46, 2020, 407-433 - http://doi.org/10.30827/cnova.v0i46.6797 


\section{Contribución ricoshombres y regidores de la ciudad de Sevilla en el pedido regio ${ }^{29}$}

\begin{tabular}{cccccc}
\hline AÑo & $\begin{array}{c}\mathrm{N}^{\circ} \text { DE } \\
\text { RICOSHOMBRES } \\
\text { Y REGIDORES }^{30}\end{array}$ & $\begin{array}{c}\text { \% POBLACIÓN } \\
\text { TOTAL DE } \\
\text { SEVILLA }^{31}\end{array}$ & CONTRIBUCIÓN & $\begin{array}{c}\text { CONTRIBUCIÓN } \\
\text { TOTAL CONTRIBUCiÓN }\end{array}$ & \\
\hline 1432 & 41 & 0,82 & 40.210 & $1.088 .035,00$ & 3,69 \\
\hline 1435 & 45 & 0,90 & 43.070 & $992.587,50$ & 4,33 \\
\hline 1445 & 47 & 0,94 & 48.950 & $1.078 .212,00$ & 4,53 \\
\hline 1453 & 66 & 1,32 & 40.500 & $786.520,00$ & 5,14 \\
\hline
\end{tabular}

Las cantidades asumidas por estos individuos en el que por esta época era el ingreso extraordinario más importante de la Corona podría parecer muy limitada en el conjunto de la contribución, si tenemos en consideración los datos aquí presentados. Su participación no superó el 5\% del total de lo aportado por la ciudad, salvo en la última fecha para la que contamos con datos. Pero si tenemos en consideración la ínfima porción de la población que estos individuos representaban — nunca por encima del $1,32 \%$ del total — podremos valorar más justamente porqué se consideraba que su aportación era indispensable para la correcta recaudación de las cifras demandadas por la Corona. Estos venían a asumir por sí solos un porcentaje contributivo similar al de algunos de los distritos fiscales más importantes de la ciudad y la relevancia de sus contribuciones no dejó de crecer con el paso del tiempo ${ }^{32}$. Además, hay que tener en cuenta que estas importantes sumas solo son un reflejo mínimo de la aportación total que haría la nobleza hispalense, ya que en estas listas solo se tiene en consideración a una mínima representación de ella. No se tiene aquí en cuenta los numerosos hidalgos, caballeros, dueñas y doncellas que debieron asumir una parte nada desdeñable en el pago de esta vía del servicio. Si sumáramos esta cantidad, la cifra resultaría aún más significativa. ¿Hasta qué punto? Una pequeña referencia

29. AMS, Pap. May., Caja 36, ff. 37r-38v y 129r-132r; Caja 38, ff. 278r-v y 285r-287r; Caja 44, ff. 220r223r y 296r-v; Caja 52, ff. 407r-409v. Las cantidades en cursiva son estimativas. Desconocemos la contribución total de Sevilla en 1453, aunque cabe presuponer que ésta fue similar a la del año siguiente, ya que la concesión de las Cortes ascendió a la misma cantidad para toda la Corona: 35 millones de maravedís (AMS, Pap. May., Caja 55, ff. 78r-81r). Por ello hemos tomado esta suma como base para nuestro cálculo.

30. El cálculo de los individuos que aparecen en estos documentos es estimativo, ya que ocasionalmente aparecen en ellos categorías imposibles de definir cuantitativamente como es el caso de "descendientes de [...]" o "Familiares de [...]".

31. Calculado en base a la estimación de un total de población de 4.974 vecinos pecheros para la primera mitad del siglo XV. Cifra calculada en base a los padrones de cuantía de este período. Para un desglose Triano, La llamada del rey, 296-307.

32. Una relación de las contribuciones del pedido en Sevilla en Triano, La llamada del rey, 693747. 
conservada en el Archivo Municipal Hispalense sobre la aportación de la segunda parte del pedido de 1436 puede darnos una pista en este sentido. Vemos cómo, según un informe generado por el concejo hispalense ese año con la intención de eximir a la nobleza sevillana, de los 387.642 maravedís que hubo de aportar la ciudad, 36.000 maravedís $(9,28 \%)$ los asumieron los ricoshombres y regidores, mientras que los caballeros, hidalgos, dueñas y doncellas aportaban 116.732 maravedís $(30,11 \%)^{33}$. Aunque estos datos son parciales - habría que sumar la contribución del primer pedido de este año para tener las cifras globales de la ciudad hispalense - muestran claramente el destacado peso contributivo de estos grupos. Aspecto que creemos se reprodujo en otros muchos núcleos de población y que, esperamos, pueda conocerse mejor conforme vaya emergiendo nueva documentación inédita de sus archivos municipales.

Otro aspecto que ha de tenerse en consideración para valorar los efectos del impacto del llamado "fuero de Andalucía" es la forma en la que este vino a afectar el estatus de los nobles que se vieron obligados a pagar. Significativamente, el perjuicio que este hecho ocasionaba a su imagen social es el argumento que los miembros de este estamento argüían con más frecuencia para contestar estas demandas fiscales. Pagar conllevaba a que se vieran igualados con los simples vecinos pecheros de sus comunidades. Si bien los efectos de esta situación pudieron diluirse un tanto en el ámbito urbano gracias a la potenciación de diversas prácticas de distinción que recordaban el predominio social de estas élites y el desarrollo de formas alternativas de contribución que permitieran distinguirlos del resto de contribuyentes, en el ámbito rural ello no siempre fue posible ${ }^{34}$. Como resultado, las capas de la baja nobleza asentadas en este tipo de espacios y ya asimiladas por nivel económico al resto de sus vecinos, vieron como su principal elemento de distinción social se diluía y su condición social venía a confundirse con el resto de población pechera ${ }^{35}$. Es posible que ello tenga mucho que ver, como han destacado algunos autores, con la decadencia que a lo largo del siglo XV muestran los hidalgos andaluces en el medio rural. Una pérdida de peso social que no fue aceptada de forma pasiva. Existió una amplia contestación a este tipo de demandas fiscales. Contestación que, en no pocas ocasiones, llegó a amenazar con quebrar la paz social de algunos municipios del espacio andaluz.

33. AMS, Pap. May. Caja 39, ff. 256r-v.

34. Rafael Sánchez Saus, "Caracterización de la nobleza medieval en el área onubense", en Huelva en la Edad Media. Reflexiones, aportaciones y nuevas perspectivas veinte años después, ed. Juan Luis Carriazo Rubio y José María Miura Andrades (Huelva: Universidad de Huelva, 1998), 56.

35. Sánchez Saus, "Caracterización de la nobleza medieval", 59. 
EN DEFENSA DEL PRIVILEGIO. CONFLICTIVIDAD EN TORNO A LA CONTRIBUCIÓN FISCAL DE LA NOBLEZA ANDALUZA (1406-1476)

La disconformidad de la nobleza andaluza a contribuir fue una constante a lo largo de todo el siglo XV. Respuesta a lo que se consideraba era un atentado a unos privilegios que muchos creían inmanentes a su posición social. Una afrenta a la que vinieron a sumarse ciertos agravios comparativos. El hecho de que los nobles de otras regiones no se vieran obligados a hacer frente a este tipo de cargas y la existencia de numerosos francos o exentos que se veían descargados de esas contribuciones fueron un constante foco de tensión y un argumento esgrimido frecuentemente contra el discurso legitimador de la Corona ${ }^{36}$. No fueron los únicos razonamientos en este sentido. Los nobles pusieron también el acento en el elevado coste que asumían ya en su lucha contra el infiel, al tiempo que recordaban que este tipo de demandas atentaban contra su tradicional libertad, sustentada en el uso y la costumbre ${ }^{37}$. La sensación de que se cometía una injusticia fue cobrando fuerza con el paso del tiempo. Sobre ella se sustentó una constante resistencia a este tipo de demandas, generando una conflictividad que vino a imbricarse estrechamente con las tensiones ya existentes dentro de cada una de las ciudades y villas de Andalucía.

Caso paradigmático de este tipo de oposición es la que mantuvieron algunos oficiales y los hidalgos de la villa de Úbeda a participar en los repartimientos de la Corona. Frente a este grupo los jurados del municipio, apoyados por los pecheros, mantuvieron un contencioso para lograr que se respetara el "fuero de Andalucía". Ya en 1435 algunos jurados ovetenses se presentaron ante el regimiento de la ciudad de Sevilla para solicitar documentación que les permitiera demostrar cómo allí los nobles y miembros de las oligarquías municipales pagaban ${ }^{38}$. Su intención era contar con pruebas que avalaran sus demandas en el pleito que estaban sosteniendo contra los nobles de su villa. Ese mismo año el monarca designaría un juez comisario, Diego de San Pedro, para que tratara esta cuestión. Sin embargo, este oficial no logró dar una verdadera solución al

36 “[...] sintiéndonos que somos muy agraviados en rrasón de pechar e seruir enlos dichos pedidos e servicios lo qual non han fecho ni fasen los otros oficiales que son delas otras dichas çibdades e villas delos rreynos e señoríos del dicho señor Rey”. AMS, Pap. May., Caja 43, ff. 96r-97v.

37. Este argumento continuaría usándose habitualmente en época moderna. Un claro ejemplo de ello lo tenemos en el pleito que don Cristóbal Ponce de León, duque de Arcos, emprendió con el concejo de Carmona a mediados del siglo XVI por esta cuestión: "no pudieron hazer repartimiento a mi parte despecho de pechero atento la calidad de persona de mi parte y su sangre y estado. Lo otro porque no aze al caso decir de ha de pechar porque pechan los hijosdalgo en la dicha villa porque conque esta costumbre se oviese es de poca consideración”. ARCHGR, Pleitos, Caja 5384, Pieza 1.

38. AMS, Pap. May., Caja 38, ff. 242r-245v. 
problema y el bloqueo de la situación favoreció una escalada de tensión que acabó desembocando en la denominada revuelta de Juan Lobatón de $1439^{39}$. Estos disturbios llevaron a que Juan II enviara a la ciudad a Juan Sánchez de Otiel, que tras diversos intentos de negociación acabó encontrando una vía de consenso. Sin embargo, la solución no contentó a todos durante mucho tiempo. Una parte del común, claramente insatisfecha, dio pie a una serie de conflictos que se prolongarían hasta 1466 con la promulgación de una célebre sentencia arbitraria. En esta se estipuló que los caballeros e hidalgos contribuirían a los repartimientos, aunque nunca más de 5 maravedíes por cabeza. La aportación fiscal sería, así, más simbólica que real. Pese a todo, se evidenciaba la fuerte capacidad de contestación por parte de los pecheros a la pretensión de la nobleza de eximirse de este tipo de contribuciones ${ }^{40}$.

No es éste el único caso que conocemos. En la ciudad de Sevilla, uno de los concejos en los que mejor documentado encontramos el proceso de recaudación de los ingresos extraordinarios de la Corona y el funcionamiento de su fiscalidad concejil, vemos cómo la oposición de los nobles a pagar fue constante $^{41}$. Tanto es así que, en 1439, los jurados de la ciudad, encargados últimos de cosechar las sumas de los diversos repartimientos en los que estos debían intervenir, elevaron un requerimiento al concejo de la ciudad solicitando una solución a este problema ${ }^{42}$. Pero la elevada capacidad de resistencia de los nobles - muchos de ellos formaban parte del concejo, donde contaban con voz y voto y una elevada capacidad de influencia - dificultaba enormemente llevar a cabo cualquier tipo de acción que los obligara a contribuir. Por ello, el regimiento hubo de limitarse a emprender algunas medidas coercitivas de corto alcance, como embargar algunos de sus salarios y rentas para tratar de cubrir estas cantidades impagadas ${ }^{43}$. Medida que no siempre fue efectiva, habiéndose de contentarse las autoridades en la mayor parte de las ocasiones con llegar a un acuerdo con estos nobles, reduciendo sensiblemente las cantidades demandadas en un primer momento ${ }^{44}$.

39. María Josefa Pareja Delgado, Baeza y Úbeda en la Baja Edad Media (Granada: Editorial don Quijote, 1988), 172-173.

40. Sobre esta cuestión Enrique Toral Peñaranda, Úbeda, 1442-1510 (Jaén: Instituto de Estudios Jienenses, 1975).

41. Francisco José Romero Romero, Sevilla y los pedidos de Cortes en el siglo XV (Sevilla: Ayuntamiento de Sevilla, 1997), 84.

42. AMS, Act. Cap., 14-VIII-1439, ff. 6-7.

43. En 1451 los contadores municipales de Sevilla darían la orden de retener el salario del duque de Medina Sidonia como alcalde mayor para afrontar las deudas que venía acumulando desde 1447 en la contribución del pedido regio. AMS, Pap. May., Caja 51, ff. 73v y 128v.

44. Por citar un simple ejemplo, vemos cómo en 1447 el Adelantado Mayor de la Frontera, Per Afán de Ribera, exigía que se le descontara la mitad de lo que se le estaba solicitando en el pago del pedido regio, demanda que parece acabó siendo aceptada. AMS, Div., Doc. 298. 
Pero si la resistencia asumida de forma unilateral y espontánea fue un hecho habitual, como ha señalado algún autor, cabe destacar también aquí unas pocas iniciativas más ambiciosas y mejor planificadas, hasta ahora un tanto ignoradas. Con ellas se trató de forzar un cambio de opinión de la monarquía en lo relativo a obligar a la nobleza a participar en las contribuciones del pedido y en ciertos empréstitos. En 1436 los hidalgos, caballeros, dueñas y doncellas de la ciudad de Sevilla se negaron frontalmente a participar en los repartimientos del pedido y demandaron que se les eximiera de forma permanente, elevando una petición al monarca ${ }^{45}$. Unos años después, en 1442, los regidores de la ciudad dieron orden de que se suspendiera la recaudación del pedido que habían de pagar, mientras solicitaban al monarca de que se les descargara en virtud de su cargo y posición, dado que así se hacía en otros lugares de la Corona ${ }^{46}$. Sin embargo, todas estas demandas acabaron cayendo en saco roto. Las causas a ello han de buscarse en la ya citada relevancia que venía teniendo la participación fiscal de la nobleza para el mantenimiento de unos ingresos sólidos y estables y en la negativa de las autoridades estatales y/o municipales a poner en riesgo un ingreso que contaba con una importancia cada vez mayor para la Real Hacienda en una de las regiones que mejor pagaban. Porque los partidos fiscales andaluces se venían caracterizando, frente a lo ocurrido en otros, por la solidez y fiabilidad de sus contribuciones a la fiscalidad extraordinaria de la Corona ${ }^{47}$.

No solo las ciudades y villas de cierto tamaño fueron testigos de este tipo de resistencias. En el ámbito rural también se produjeron contestaciones a estas demandas fiscales y, eventualmente, estos movimientos parece que mostraron mayores niveles de organización que en ciudades y villas de mediano y gran tamaño. Así lo observamos en algunas localidades del alfoz hispalense. Allí, hidalgos y caballeros solían organizarse para hacer frente común ante las demandas del concejo, como ocurrió en Fregenal de la Sierra en 1439, cuando los hidalgos de la villa se querellaron por haber sido acontiados (inscritos en los padrones) o en Aracena en 1448, cuando cerca de una treintena de personas se negaron a pechar aludiendo a su condición privilegiada ${ }^{48}$.

Conscientes de que las autoridades fiscales no transigirían con sus demandas y tratando de que su contribución al pedido regio y otros repartimientos extraordinarios afectaran lo menos posible a su patrimonio y su estatus social, los nobles buscaron formas de distinguir su participación fiscal de las del común de los pecheros. Algo que lograron gracias a la connivencia de los gobiernos

45. AMS, Pap. May, Caja 39, f. 132r.

46. AMS, Pap. May., Caja 43, ff. 96r-97v.

47. José Manuel Triano Milán y Julieta Rodríguez Sarria, “Algunas consideraciones en torno a la concesión, recaudación y gasto del pedido regio en Sevilla y su tierra en 1454", En la España Medieval, vol. 38 (2015): 336.

48. AMS, Act. Cap., 6-III-1439 y 11-V-1448. 
municipales. En este sentido, la primera distinción fue lograr que en algunos concejos no se procediera a la valoración de sus haciendas o que esta se realizara de manera independiente a las del resto de contribuyentes ${ }^{49}$. En Sevilla desde 1432 los más eminentes ricoshombres y los regidores y alcaldes del concejo dejaron de ser contemplados por los padrones en los que se solía cuantificar la riqueza de los pecheros antes de hacer el pertinente reparto del pedido ${ }^{50}$. En su lugar, fueron incluidos en esas hojas de repartimiento que mencionábamos anteriormente, en las que se valoraba su contribución de forma no proporcional a su riqueza, sino por una carga que respondía a una apreciación subjetiva del concejo. Hidalgos y caballeros no lograron una distinción similar. Al menos no hasta la década de 1480, cuando empezaron a ser inscritos aparte y sin notificar sus cuantías, tal y como se observa en el ámbito del alfoz ${ }^{51}$. Y no fue Sevilla el único lugar en el que este estamento alcanzó este tipo de éxito. En el caso de algunos municipios del antiguo reino de Jaén observamos la existencia de padrones de hidalgos, que se redactaban en paralelo a los que se conformaban para el resto de los pecheros ${ }^{52}$. Y allí donde estos elementos de distinción no se aplicaban tan claramente - lo que parece ser la situación más generalizada en los reinos de Córdoba y Sevilla - hemos de recordar que los más pudientes se vieron beneficiados por la habitual injerencia de los concejos en los sistemas de cáñamas, favoreciendo a las cuantías más altas con unas cargas inferiores a las que deberían haber asumido ${ }^{53}$.

Tampoco los procedimientos de recaudación fueron siempre exactamente los mismos para la nobleza que para el resto de los contribuyentes. Una vez más encontramos en Sevilla una clara muestra de ello. En lo referente a la recaudación de las contribuciones de los ricoshombres asentados en la ciudad vemos cómo lo más frecuente es que los encargados de la cosecha de estos repartimientos se pusieran directamente en contacto con los mayordomos de su casa, no molestando a la cabeza del linaje con este tipo de asuntos. Además,

49. Las contribuciones extraordinarias de la Corona (pedidos, empréstitos, repartimientos militares), así como algunas de las demandadas por el concejo se recaudaban teniendo en cuenta la hacienda con la que contaba cada pechero, tras un proceso conocido como acontiamiento. La pretensión es que la carga fiscal respondiera al principio de justicia distributiva ya enunciado por Aristóteles. En torno a esta cuestión véase Collantes de Terán, Sevilla en la Baja Edad Media, 20-30 y Triano, La llamada del rey, 141-143.

50. El primero de estos documentos que hemos podido localizar pertenece a este año. El mismo se localiza en AMS, Pap. May., Caja 36, ff. 37r-38v.

51. Mercedes Borrero Fernández, El mundo rural sevillano en el siglo XV: Aljarafe y Ribera (Sevilla: Diputación provincial de Sevilla, 1983), 363.

52. Sobre este tipo de padrones Pareja Delgado, Baeza y Úbeda, 60.

53. Juan Manuel Carretero Zamora, "Las oligarquías locales y los mecanismos de exención del servicio de Cortes en la época de Carlos V", Espacio, Tiempo y Forma, Serie IV, Ha Moderna, t. 11 (1998): 31 y ss.

Chronica Nova, 46, 2020, 407-433 - http://doi.org/10.30827/cnova.v0i46.6797 
la constante resistencia mostrada por los nobles hispalenses a participar en los repartimientos del pedido y los problemas que ello les generaba a los jurados de la ciudad, que habitualmente cosechaban estas sumas, determinó que el concejo decidiera que a partir de 1447 fueran los recaudadores mayores los encargados directamente de hacer efectivo este proceso ${ }^{54}$. Se suponía que al contar con un grado mayor de autoridad lograrían forzar el pago allí donde los oficiales del concejo habían fracasado. Pero lo cierto es no se logró acabar con el problema. En no pocas ocasiones fueron los concejos los que acabaron asumiendo este tipo de cargas, ya fuera para evitar posibles conflictos, ya para contentar a unas figuras que gozaban de una posición central en la política local o, incluso, como contraprestación a algún favor que estos individuos habían realizado a la institución.

\section{UN NUEVO PACTO FISCAL. LA PAULATINA SUSTRACCIÓN DE LA NOBLEZA ANDALUZA AL PAGO DE LAS CONTRIBUCIONES (1476-PRINCIPIOS SIGLO $X V I)$}

Tras una última gran demanda de recursos al reino en las Cortes de Madrigal de 1476, Fernando V e Isabel I iniciaron una reforma de amplio alcance en el sistema de ingresos extraordinarios de la Corona. Los servicios de Cortes, que habían venido mostrando una fuerte degradación desde la década de los treinta, fueron sustituidos por las contribuciones para el mantenimiento de la nueva Hermandad General ${ }^{55}$. El pacto fiscal existente entre rey y reino experimentó, así, una profunda revisión, como se refleja en los intensos debates que acompañaron a esta nueva decisión. Prácticamente no quedó tema por tratar: desde el modelo de ingresos hasta las principales partidas de gasto, pasando por la estructura institucional generada para controlar la extracción y gestión de estos ingresos y la organización administrativo-territorial ${ }^{56}$. Uno de los aspectos que mayor polémica generó fue la pretensión por parte de las autoridades rectoras de la Hermandad de iniciar una completa revisión del cuerpo de contribuyentes. Así, aprovechando que el ingreso había sido creado ex novo y no estaba marcado

54. AMS, Pap. May. Caja 50, ff. 417r-420r.

55. Sobre el sistema fiscal de la Santa Hermandad contamos con una bibliografía cada vez más amplia. Remitimos aquí a algunas síntesis interpretativas sobre la cuestión como las de Miguel Ángel Ladero Quesada, La Hermandad de Castilla. Cuentas y memoriales (Madrid: Real Academia de la Historia, 2005); Pablo Ortego Rico, "La «contribución» de la Hermandad en Castilla la Nueva: modelos tributarios y poderes concejiles (1476-1498)", Chronica Nova, $\mathrm{n}^{\circ} 41$ (2015): 275-323 у Triano, ¿Un nuevo sistema de fiscalidad extraordinaria?", 172-174.

56. Triano, “¿Un nuevo sistema de fiscalidad extraordinaria?”, 174. 
por la existencia de antiguos usos y privilegios se trató de hacer participar a todos los súbditos de la Corona en ellos, incluyendo a la nobleza y el clero ${ }^{57}$. Se consideraba que, ya que la labor de la institución redundaba en el bien común, todos, sin excepción, debían ayudar a mantenerla ${ }^{58}$. No obstante, la amplia oposición que el estamento nobiliario mostró a la implantación de la Hermandad obligó a que las autoridades se replantearan esta decisión, buscando vías para un consenso sin el que la implantación de esta institución no resultaba viable. De esta forma, la exención de la nobleza y el clero acabó siendo ratificada. Una relevante victoria para unos estamentos privilegiados que no solo lograron anular el envite de la Corona contra sus tradicionales exenciones, sino que lograron que estas alcanzaran mayor brillo, ya que el resto de franquezas existentes fueron, por lo general, anuladas por el sistema tributario hermandino ${ }^{59}$.

Por su parte, oficiales y regidores de las ciudades y villas andaluzas lograron finalmente la ansiada exención en virtud de la labor que desempeñaban ${ }^{60}$. Un éxito que podemos interpretar como una compensación por parte de la Corona por el creciente papel que estas autoridades venían desempeñando en la maquinaria administrativo-fiscal de la Corona ${ }^{61}$. No ocurrió lo mismo con el conjunto de la nobleza andaluza, tal y como evidencia una carta enviada por los monarcas al concejo de Carmona en 1483 recordándoles a caballeros e hidalgos que no podían eximirse de las contribuciones:

non lo podiendo nin deuiendo faser de derecho, porque en la dicha villa e en todas las çibdades e villas e logares del Andalusía, desde que la dicha tierra se ganó de los moros fasta agora, syenpre acostumbraron pechar e contribuyr todos los fijosdalgo que en ella biuen en todos los seruiçios reales e conçejiles que en las dichas çibdades e villas e logares del Andalusía han echado e repartido y echan e reparten ${ }^{62}$.

57. Tal y como se muestra en las disposiciones de las Junta de Dueñas de 1476. AGS, Div. Cast., Leg. 8. Doc. 2. Documento transcrito y publicado por José María Sánchez Benito y Yolanda Guerrero Navarrete, "El proceso constituyente de la Hermandad General. Los ordenamientos de 1476 a 1478", Anuario de Historia del Derecho Español, n 59, (1989): 650-651.

58. "E porque a los prinçipios que esta Hermandad se constituyó, considerando que la utilidad era común a todos, caualleros e escuderos e hidalgos, fue ordenado que todos contribuyesen a ella [...]". Fernando del Pulgar, Crónica de los Reyes Católicos. Tomo I. Ed. Juan de Mata Carriazo y Gonzalo Ponto Gijón, (Granada: Marcial Pons, 2008), 242.

59. Sobre la reducción de las franquezas a las que dio lugar el nuevo modelo fiscal de la Santa Hermandad véase Collantes de Terán, "Los sevillanos ante el impuesto", 311.

60. Carretero, "Las oligarquías locales y los mecanismos de exención", 13.

61. Triano, “¿Un nuevo sistema de fiscalidad extraordinaria?”, 187.

62. AMC, Leg. 7, f. 10v. Fragmento citado por Collantes de Terán, "Los sevillanos ante el impuesto", 309-310. 
No obstante, aunque pudiera parecerlo a la luz de este texto, la situación no continuó igual. Si bien la normativa siguió insistiendo en la necesidad de que participaran en los repartimientos extraordinarios, en la praxis los nobles andaluces lograron ir eximiéndose de su pago. Algo posible gracias a una serie de novedades fiscales y políticas que supieron explotar hábilmente en su favor. En primer lugar, pese a algún recordatorio eventual sobre la cuestión, la Corona mantuvo una actitud un tanto laxa en la aplicación de esta normativa. Aspecto que parece reflejarse en las nulas referencias a la definición del cuerpo de contribuyentes en las cartas de solicitud de las aportaciones de la Hermandad que eran enviadas a los distintos concejos andaluces a lo largo de estos años ${ }^{63}$. Esta actitud parece ser el resultado de la necesidad de las autoridades tributarias de transigir un tanto con las pretensiones de un estamento que se había mostrado sumamente combativo frente a la implantación de la institución y del que se esperaba un alto grado de colaboración en el sostenimiento del nuevo reinado y de los ambiciosos proyectos de los monarcas sobre el reino nazarí de Granada ${ }^{64}$. La posterior participación de la nobleza andaluza en este conflicto pudo ayudar a que la monarquía decidiera mantener este statu quo, no interfiriendo excesivamente sobre esta cuestión. Otro aspecto que hemos de tener en consideración en lo relativo a la sustracción del pago de estas contribuciones fue la radical transformación que experimentaron los mecanismos de recaudación de los ingresos extraordinarios a lo largo de este período, sustituyéndose generalmente los sistemas de extracción directa por otros de carácter indirecto o el recurso a los propios del concejo ${ }^{65}$. Cuando se aplicaron imposiciones o sisas los nobles se vieron un tanto descargados gracias a su elevado nivel de autoconsumo y el desvío de buena parte de la carga contributiva hacia grupos foráneos en la $\operatorname{ciudad}^{66}$. En el segundo de estos escenarios, se procedía al mantenimiento del gasto con unos recursos que solían proceder de unos pechos concejiles de los

63. Collantes de Terán, "Los sevillanos ante el impuesto", 309-310. Aspecto que contrasta con el detalle que se prestaba a esta cuestión en las cartas de demanda del pedido y las monedas a lo largo de buena parte del siglo XV. Romero Romero, Sevilla y los pedidos de Cortes, 19-20.

64. Que estos proyectos sobre Granada y la pretensión de que la Hermandad ejerciera un papel relevante en los mismos estuvieron muy presentes desde la conformación de la institución resulta evidente si atendemos a testimonios como un memorial anónimo presentado ante los monarcas en la Junta de Dueñas (1476). Este documento lo hemos transcrito en Triano, "De la restauración de la justicia a la lucha contra el infiel", 130-131.

65. Antonio Collantes de Terán Sánchez, "Teoría y práctica de la obligación fiscal en la Andalucía bajomedieval: impuestos directos versus impuestos indirectos", Andalucía, España, las Indias: pasión por la historia. Homenaje al profesor Antonio Miguel Bernal, ed. en Carlos Martínez Shaw; Pedro Tedde de Lorca y Santiago Tinoco Rubiales (Madrid: Universidad de Sevilla y Marcial Pons, 2015); José María Navarro Sainz, "Aproximación al estudio de la Hermandad General bajo los Reyes Católicos en Sevilla y su tierra”, Historia. Instituciones. Documentos, no 33 (2006): 467 y ss. y Ortego Rico, "La «contribución» de la Hermandad en Castilla la Nueva", 297 y ss.

66. Carretero, "Las oligarquías locales y los mecanismos de exención”, 34-35. 
que habitualmente los nobles se encontraban completamente eximidos, lo que resultaba aún más ventajoso.

Como resultado, la conflictividad no desapareció, sino que incluso se intensificó. O eso parece indicar la multiplicación de referencias en la documentación municipal a este tipo de tensiones. La creciente presión fiscal que la Corona venía a ejercer sobre los municipios y las necesidades de gasto cada vez más amplias de las haciendas locales llevó a que aumentaran los intentos para ampliar la base de contribuyentes ${ }^{67}$. Aspecto que vino a entrelazarse con algunas tensiones sociales generadas por la pretensión de ciertos grupos de alcanzar un mayor peso social y político a nivel local. En este sentido, resulta paradigmático lo ocurrido en la ciudad de Córdoba, donde los caballeros de premia iniciaron una amplia ofensiva para lograr una posición más destacada en la ciudad y sustraerse un tanto de la creciente carga contributiva a la que se veían obligados a hacer frente ${ }^{68}$. Para ello utilizaron el "fuero de Andalucía", recordando no solo la obligación de los hidalgos a la hora de contribuir en los repartimientos extraordinarios de la Corona sino incluso poniendo en cuestión su posición social ${ }^{69}$. El objetivo era lograr igualar la condición de los caballeros de premia y de los hidalgos, quebrando el monopolio que estos últimos solían mantener sobre los cargos de gobierno en el municipio y la preeminencia social que habían venido manteniendo hasta el momento.

Frente a este tipo de pretensiones, se produjo una progresiva revalorización del concepto de hidalguía. Algo posible gracias al apoyo de unos monarcas que empiezan a ejercer un fuerte control sobre el acceso a los sectores bajos y medios de la nobleza ${ }^{70}$. Frente a las ambiciones de otros sectores sociales, los hidalgos y caballeros se mostraron especialmente reivindicativos a la hora de reafirmar los privilegios y exenciones que acompañaban a su condición. Eran conscientes que la pérdida de cualquiera de estas prerrogativas, que eran vistas como un conjunto inseparable, podía suponer la pérdida de la totalidad. Si se quería impedir una situación similar a la que habían soportado en tiempos pasados, cuando la condición de caballeros e hidalgos se había visto un tanto en entredicho en ciertas

67. Sobre la creciente presión fiscal al que se vieron sometidos estos concejos véase Antonio Collantes de Terán Sánchez, "Fiscalidad de Estado y concejos en el reino de Sevilla durante el reinado de los Reyes Católicos (1474-1504)", en Fiscalidad de Estado y fiscalidad municipal en los reinos hispanos medievales, ed. Denis Menjot y Manuel Sánchez Martínez (Madrid: Casa de Velázquez, 2006), 113-117.

68. Quintanilla y Asenjo, "Los hidalgos en la sociedad andaluza", 431.

69. "[...] sobre que en esta çibdad de Córdoua se guarde el fuero antiguo que diz que disponia que todos los vesinos e moradores de esta dicha çibdad agora fuesen fijosdalgo o no, todos ouiesen de ser caualleros de contía". AGS, CC, Pueb, Leg. 6, f. 268.

70. Centenero, "De lo cuantitativo a lo cualitativo", 294 y Quintanilla y Asenjo, "Los hidalgos en la sociedad andaluza", 420 y ss. 
regiones andaluzas, no podía asumirse sin más la obligación de contribuir en los pechos concejiles y las demandas extraordinarias de la monarquía. Era necesario mantener o incluso reforzar la distancia con respecto a otros emergentes grupos sociales ${ }^{71}$. Esta situación experimentó un desarrollo aún mayor a partir de la publicación de la célebre Pragmática de Córdoba en $1492^{72}$. En este documento se establecía que la prueba más relevante para justificar la condición de hidalgo era demostrar que sus antepasados habían gozado de la exención de pechos al menos durante tres generaciones. Así, el fuero de Andalucía cobró aún mayor relevancia en todos aquellos procesos vinculados a la defensa de esta condición y de los privilegios que les eran propios. Todo ello en el contexto de una creciente judicialización de este tipo de cuestiones, que consolidó una particular visión de la condición nobiliaria y obligó a una continua revisión de su significado ${ }^{73}$. Así se refleja en la ciudad de Sevilla y su tierra, donde Michael L. Crawford ha llegado a contabilizar hasta setenta pleitos por esta cuestión en el período comprendido por el reinado de los Reyes Católicos ${ }^{74}$. Pleitos que no dejarían de aumentar durante las décadas siguientes ${ }^{75}$.

Junto a los aspectos ya señalados, vemos como en este tipo de pleitos medió también la pretensión de las autoridades concejiles de discutir la condición noble de estos individuos, especialmente aquellos que procedían de fuera del concejo. Se trataba de una vía para reforzar su base pechera y, sobre todo, una forma de cerrar la estructura social ante unos individuos que podían trastocar los equilibrios de poder en el ámbito local ${ }^{76}$. Otro aspecto que hemos de tener en consideración aquí fue el elevado número de abusos que debió suscitar esta cuestión. Eran muchos los que trataban de alcanzar la categoría de hidalgo sin tener verdadero derecho a ello, mediante una teórica exención fiscal que no era tal y un falseamiento de sus orígenes ${ }^{77}$. La presencia de estos falsos hidalgos no dejó de cobrar importancia con el paso del tiempo, especialmente como resultado del apoyo prestado por algunos concejos a este tipo de grupos, ayudándoles en la aplicación de su fraude ${ }^{78}$.

71. Michael J. Crawford, The fight for status and privilege in Late medieval and Early modern Castile (1465-1598). (University Park: Pennsylvania State University Press, 2014), 61.

72. Nueva Recopilación, libro II, título XI, ley VIII.

73. Centenero, "De lo cuantitativo a lo cualitativo", 294.

74. Crawford, The fight for status, 35.

75. Crawford, The fight for status. Otra interpretación cuantitativa en Centenero, "De lo cuantitativo a lo cualitativo", 297.

76. Janine Fayard, Janine y Marie-Claude Gerbet, "Fermeture de la noblesse et pureté de sang dans les concejos de Castille au XVème siècle à travers les procès d'hidalguía", En la España Medieval, $\mathrm{n}^{\circ} 6,(1985): 72$.

77. Carretero, "Las oligarquías locales y los mecanismos de exención", 23 y Fayard y Gerbet, "Fermeture de la noblesse", 67.

78. Carretero, "Las oligarquías locales y los mecanismos de exención", 23. 
Frente al aumento de este tipo de pleitos, amparados por cierto caos normativo heredado de los reinados anteriores ${ }^{79}$, la actuación de los concejos como tribunales de primera instancia vino a complicar un tanto la situación. La desigual apreciación del problema como resultado de la aplicación de ordenamientos jurídicos de carácter local muy diferentes entre sí y la ya señalada tendencia de las autoridades a interpretar el estatus del individuo según sus particulares intereses generó una fuerte sensación de agravio en amplias capas de la población. Estos agraviados tendieron a recurrir, cada vez más, a la mediación de la Corona o a la de los tribunales directamente vinculados a ella ${ }^{80}$. Se generaba, así, otro marco de injerencia más del poder real en la jurisdicción de los concejos, que mostraron cierta resistencia a esta nueva situación ${ }^{81}$. Habitualmente, la autoridad monárquica y sus oficiales tendieron a confirmar los privilegios de los hidalgos, aunque recordando que estos habrían de participar en aquellos pechos y derechos en los que existía uso y costumbre de contribuir. No obstante, no se solía explicitar cuáles eran dichas contribuciones, lo que era aprovechado por estos individuos, que muchas veces se habían eximido ya de facto de estas aportaciones, para lograr una ratificación de su privilegio.

Pero no todos los conflictos por la contribución de la nobleza se dirimieron de esta forma, aunque esta fuera la tendencia general. Algunos concejos siguieron intentando aplicar el fuero de Andalucía no solo sobre hidalgos y caballeros, sino también sobre insignes representantes de la nobleza andaluza. Sorprende observar que en los casos en los que tenemos documentados este tipo de conflictos, como es el caso del pleito entre el concejo de Carmona y el duque de Arcos en 1554, ambas partes utilizaron el argumento del uso y la costumbre como base de su pretensión $^{82}$. Así, mientras los concejos siguieron esgrimiendo una práctica que había ido cayendo cada vez más en desuso, los nobles andaluces se aferraron a los privilegios tradicionalmente reconocidos de su estamento e hicieron la vista gorda ante la obligación que habían soportado sus antepasados a la hora de pechar. El olvido interesado de la excepcional situación fiscal que había tenido

79. Piénsese en el problema generado por Enrique IV durante los años de la guerra civil, cuando ofreció el título de hidalgo a todo aquel que acudiera con armas a sostener su causa mientras su Real se encontraba asentado en Simancas. Posteriormente, estas medidas fueron revocadas, pero muchos de los beneficiados por ella se negaron a perder su condición, generando serios conflictos a nivel local. Cortes, Tomo III, 782-785 (Cortes de Ocaña de 1469, Petición 6). Gerbet, "Les guerres et l'accès a la noblesse", 295.

80. Crawford, The fight for status, 43.

81. Sobre esta cuestión, en la que median otras consideraciones como la extensión de los corregimientos o la implantación de la Santa Hermandad, véase Marvin Lunenfeld, Los corregidores de Isabel la Católica (Barcelona: Labor, 1989), 62.

82. ARCHGR, Pleitos, Caja 5384, Pieza 1.

Chronica Nova, 46, 2020, 407-433 - http://doi.org/10.30827/cnova.v0i46.6797 
la nobleza andaluza hasta finales del siglo XV se convierte así en un elemento recurrente en los pleitos sobre esta cuestión de época moderna. La desaparición de la frontera, esta persistente resistencia por parte de la nobleza y la laxitud en la definición y aplicación de la normativa fiscal referente a ella por parte de la Corona favoreció que los efectos del fuero de Andalucía se fueran diluyendo con el paso del tiempo.

\section{CONCLUSIONES}

La obligación de la nobleza andaluza a participar en algunas cargas reales y concejiles es una muestra más de la relevancia que tuvo la frontera en la articulación de las estructuras fiscales en el espacio castellano. Tradicionalmente se ha venido poniendo el acento sobre cómo la emergencia que generaba la constante amenaza musulmana potenció la conformación de unas haciendas municipales muy precoces y, con el paso del tiempo, reforzó la autoridad fiscal de la monarquía sobre estos espacios ${ }^{83}$. Pues bien, uno de los máximos ejemplos de ello fue la capacidad con la que contaron las autoridades locales para demandar a la poderosa nobleza andaluza, incluyendo a sus miembros más destacados, su activa participación en ciertos ingresos fiscales reales y concejiles. Aspecto que favoreció que esta región mantuviese unos niveles de contribución más sólidos y estables de los de otros espacios de la Corona a su emergente fiscalidad extraordinaria. Sin embargo, como contrapartida, este tipo de demandas actuaron como un revulsivo en las complejas relaciones sociales dentro de los concejos andaluces, canalizando unas tensiones que encontraron una vía de expresión un tanto diferente que en otras partes de Castilla. Los conflictos intra e interestamentales encontraron un punto de unión en el denominado "fuero de Andalucía", imbricándose con la cuestión fiscal. La particular relación de cada individuo o estamento con los emergentes sistemas tributarios locales y estatales se vinculaba muy estrechamente con su propia condición social. El cuestionamiento de este tipo de privilegio podía llegar a suponer un atentado directo contra su estatus. Por

83. Algunas consideraciones sobre sobre esta cuestión en Denis Menjot y Antonio Collantes de Terán Sánchez, "La genesis de la fiscalidad municipal en Castilla: primeros enfoques", Revista d'Historia Medieval, $\mathrm{n}^{\circ} 7$ (1996): 79 y Denis Menjot, "Système fiscal étatique et systèmes fiscaux municipaux en Castille (XIII ${ }^{\mathrm{e}} \mathrm{s}$.-fin du XV ${ }^{\mathrm{e}} \mathrm{s}$.)", en Fiscalidad de Estado y fiscalidad municipal en los reinos hispánicos medievales, ed. Denis Menjot y Manuel Sánchez Martínez (Madrid: Casa de Velázquez, 2006), 26 y 34. Una reflexión general sobre cómo el conflicto con el infiel vino a reforzar la soberanía tributaria en Castilla, generando un sistema fiscal más precoz y desarrollado que la de otras potencias vecinas véase Denis Menjot, "Taxation and sovereignty in medieval Castile", en Authority and spectacle in Medieval and Early Modern Europe. Essays in honor of Teófilo F. Ruiz, ed. Yuen-Gen Liang, y Jarbel Rodríguez (Londres: Roudletge, 2017), 96. 
ello, el "fuero de Andalucía" fue utilizado por ciertos grupos como medio para debilitar el predominio político de la nobleza andaluza o defender sus posiciones políticas frente a esta. Por su parte, nobles e hidalgos trataron de sustraerse casi siempre de una obligación que podía llegar a poner en peligro el conjunto de sus honras, mercedes y privilegios, ya que cuestionar una parte de estos suponía cuestionar un conjunto que era apreciado como indivisible. Cuando la capacidad de sustraerse de esta carga se mostró como una pretensión imposible, trataron de paliar sus efectos, recordando que su contribución era una muestra más de su compromiso con el bien común y que en modo alguno afectaba a una libertad de derecho que les era propia por sangre. En la práctica, además, trataron de que esta distinción se aplicara en los medios mediante los que se evaluaba su patrimonio y contribuían a este tipo de demandas fiscales, recordando que no eran iguales al resto de los pecheros.

Pese a lo anteriormente expuesto, no hemos de olvidar que los conflictos sociales en torno a la diferenciación de la condición de hidalgos y vecinos pecheros, con la fiscalidad como uno de sus aspectos centrales, fue un fenómeno extensivo a buena parte de la Corona castellana a lo largo de este período. Aunque en el espacio andaluz adoptó las particulares condiciones que hemos descrito, muchos aspectos de estos conflictos pueden ser puestos en relación, por ejemplo, con la compleja situación descrita por el profesor Díaz de Durana para el ámbito de la cordillera cantábrica a finales de la Edad Media ${ }^{84}$. Creemos que un estudio más amplio, que emprenda la comparación de algunas extensas regiones del espacio castellano, podría resultar sumamente esclarecedora para una mejor comprensión de este problema, ahora que los estudios de caso son lo suficientemente abundantes.

Como no podía ser de otra manera, la participación fiscal de la nobleza experimentó sensibles cambios al calor de la compleja evolución de los sistemas fiscales y de la articulación de las relaciones políticas entre este estamento y la Corona. Contrariamente a lo defendido por cierta historiografía, que ha interpretado el paso del domain al fiscal State defendido por Joseph A. Schumpeter de manera un tanto esquemática y progresiva, la paulatina sustracción de la nobleza andaluza al pago de estas contribuciones nos permite observar que la historia de estos emergentes sistemas tributarios no es la de unas estructuras que fueron imponiendo de forma paulatina y unilateral su creciente autoridad sobre los otros cuerpos políticos ${ }^{85}$. Así mismo, en esta compleja relación hemos de

84. José Ramón Díaz de Durana, "Sobre la condición hidalga o pechera del campesinado en el entorno de la cordillera cantábrica al final de la Edad Media", en La pervivencia del concepto. Nuevas reflexiones sobre la ordenación social del espacio en la Edad Media, coord. José Ángel Sesma Muñoz y Carlos Laliena Corbera (Zaragoza: Universidad de Zaragoza, 2008), 397-399.

85. La interpretación del célebre economista austriaco en un artículo publicado originalmente antes de la Primera Guerra Mundial. Una traducción en castellano de este texto en Joseph Alois 
tener en cuenta el papel de otro actor fundamental. Nos referimos a esas élites municipales que vinieron a ejercer una creciente influencia en el plano local, conforme fue creciendo su importancia en el aparato administrativo-fiscal del emergente Estado castellano y recibieron una autonomía de gestión más elevada en lo referente a la recaudación y gestión de los ingresos de la Corona. Desde principios del siglo XVI el resultado de todo ello es un panorama sumamente complejo, en el que predomina el cruce de intereses a escala local y regional sobre un marco normativo difuso y el recuerdo de una práctica fiscal vinculada a una frontera que se había trasladado ya a otro espacio, con unas condiciones sensiblemente diferentes ${ }^{86}$.

\section{BIBLIOGRAFÍA}

Borrero Fernández, Mercedes. El mundo rural sevillano en el siglo XV: Aljarafe y Ribera. Sevilla: Diputación provincial de Sevilla, 1983.

Carretero Zamora, Juan Manuel. "Las oligarquías locales y los mecanismos de exención del servicio de Cortes en la época de Carlos V", Espacio, Tiempo y Forma, Serie IV, $\mathrm{H}^{\mathrm{a}}$ Moderna, t. 11 (1998): 11-38.

- La averiguación de la Corona de Castilla, 1525-1540. Los pecheros y el dinero del reino en época de Carlos V. 3 vols. Valladolid: Junta de Castilla y León, 2008.

- "Los concejos castellanos y el régimen señorial ante la Real Hacienda. La gestión de los servicios (1500-1556)". En Tesoreros, arrendadores y financieros en los reinos hispánicos: la Corona de Castilla y el reino de Navarra (siglos XIV-XVII), editado por Ernesto García Fernández. Madrid: Instituto de Estudios Fiscales y Universidad de Málaga, 2012, 195-218.

Centenero de Arce, Domingo. "De lo cuantitativo a lo cualitativo. Los pleitos de hidalguía y la tratadística jurídica", Obradoiro de Historia Moderna, $\mathrm{n}^{\circ}$ 24 (2015): 289-308.

Collantes de Terán Sánchez, Antonio. Sevilla en la Baja Edad Media. La ciudad y sus hombres. Sevilla: Ayuntamiento de Sevilla, 1984.

- "Fiscalidad de Estado y concejos en el reino de Sevilla durante el reinado de los Reyes Católicos (1474-1504)", en Fiscalidad de Estado y fiscalidad

Schumpeter, "La crisis del Estado fiscal", Revista Española de Control Externo, vol. 2, n ${ }^{\circ} 5$ (2000): 147-192.

86. Sobre la evolución de la frontera y su impacto general en la vida social, económica y política castellana sigue siendo especialmente útil la brillante síntesis de Andrew C. Hess, The forgotten frontier. A History of the Sixteenth-Century Ibero-African frontier. (University of Chicago Press: London, 2000). 
municipal en los reinos hispanos medievales, editado por Denis Menjot y Manuel Sánchez Martínez, 113-134. Madrid: Casa de Velázquez, 2006.

- "Los sevillanos ante el impuesto: la exención fiscal (siglos XIII-XVI)", Minervae Baeticae, $\mathrm{n}^{\circ} 41$ (2013): 293-318.

- "Teoría y práctica de la obligación fiscal en la Andalucía bajomedieval: impuestos directos versus impuestos indirectos". En Andalucía, España, las Indias: pasión por la historia. Homenaje al profesor Antonio Miguel Bernal. Editado por Carlos Martínez Shaw; Pedro Tedde de Lorca y Santiago Tinoco Rubiales. Madrid: Universidad de Sevilla y Marcial Pons, 2015.

Crawford, Michael J. The fight for status and privilege in Late medieval and Early modern Castile (1465-1598). University Park: Pennsylvania State University Press, 2014.

Díaz de Durana y Ortiz de Urbina, José Ramón., "Sobre la condición hidalga o pechera del campesinado en el entorno de la cordillera cantábrica al final de la Edad Media”. En La pervivencia del concepto. Nuevas reflexiones sobre la ordenación social del espacio en la Edad Media, coordinado por José Ángel Sesma Muñoz y Carlos Laliena Corbera, 381-408. Zaragoza: Universidad de Zaragoza, 2008.

Díaz de la Guardia y López, Luis. "Exención fiscal nobiliaria en el ámbito local bajomedieval. En torno a tres documentos de la villa de Belmonte", Espacio, Tiempo y Forma, Serie III, Historia Medieval, t. 19 (2007): 137-173.

— "Los pleitos plenos de hidalguía en la Baja Edad Media: una posible evolución jurídica bajo los Trastámaras desde la óptica de la Edad Moderna", Espacio, Tiempo y Forma, Serie III, Historia Medieval, t. 21 (2008): 41-108. Domínguez Ortiz, Antonio. Las clases privilegiadas en el Antiguo Régimen. Madrid: Akal, 2012.

Fayard, Janine y Gerbet, Marie Claude. "Fermeture de la noblesse et pureté de sang dans les concejos de Castille au XVème siècle à travers les procès d'hidalguía", En la España Medieval, nº 6, (1985): 51-75.

Gerbet, Marie Claude. "Les guerres et l'accès à la noblesse en Espagne de 14651592", Mélanges de la Casa Velázquez, VII (1972): 295-326.

- La nobleza en la Corona de Castilla. Sus estructuras sociales en Extremadura (1454-1516). Cáceres: Diputación provincial de Cáceres, 1989.

González González, Raúl. "La exención fiscal, entre el privilegio y el conflicto: los excusados de la Iglesia en Astorga, León y Oviedo", Historia. Instituciones. Documentos, $\mathrm{n}^{\circ} 42$ (2015): 157-197.

González Jiménez, Manuel. "Poblamiento y frontera en Andalucía (ss. XIIIXV)", Espacio, Tiempo y Forma, Serie III, Historia Medieval, t. 4 (1989): 207-224.

Guillén Berrendero, José Antonio. "La tratadística nobiliaria como espejo de nobles. El ejemplo de Juan Benito Guardiola y su tratado de nobleza de 1591", Brocar: cuadernos de investigación histórica, $\mathrm{n}^{\mathrm{0}} 26$ (2002): 81-106. 
— "El reconociendo a los nobles y católicos castellanos en tiempos de Santa Teresa de Jesús. Una reflexión sobre la tratadística nobiliaria y la presencia de la devoción”, eHumanista: Journal of Iberian Studies, vol. 33, (2016): 191-211.

Hess, Andrew C. The forgotten frontier. A History of the Sixteenth-Century Ibero-African frontier. Londres: University of Chicago Press, 2000.

Ladero Quesada, Miguel Ángel. La Hermandad de Castilla. Cuentas y memoriales. Madrid: Real Academia de la Historia, 2005.

Lunenfeld, Marvin. Los corregidores de Isabel la Católica. Barcelona: Labor, 1989.

Menjot, Denis. "Système fiscal étatique et systèmes fiscaux municipaux en Castille (XIII ${ }^{\text {e }}$ s.-fin du XV ${ }^{\text {e }}$ s.)". En Fiscalidad de Estado y fiscalidad municipal en los reinos hispánicos medievales, editado por Denis Menjot y Manuel Sánchez Martínez. Madrid: Casa de Velázquez, 2006, 21-51.

- "Taxation and sovereignty in medieval Castile". En Authority and spectacle in Medieval and Early Modern Europe. Essays in honor of Teófilo F. Ruiz, editado por Yuen-Gen Liang, y Jarbel Rodríguez. Londres: Roudletge, 2017. Menjot, Denis y Collantes de Terán Sánchez, Antonio. "La génesis de la fiscalidad municipal en Castilla: primeros enfoques", Revista d'Historia Medieval, $\mathrm{n}^{\circ} 7$ (1996): 53-80.

Morsel, Joseph. La aristocracia medieval. El dominio social en Occidente (siglos $V-X V$ ). Valencia: Universidad de Valencia, 2008.

Navarro Sainz, José María. “Aproximación al estudio de la Hermandad General bajo los Reyes Católicos en Sevilla y su tierra", Historia. Instituciones. Documentos, $\mathrm{n}^{\circ} 33$ (2006): 457-485.

Ortego Rico, Pablo. "La «contribución» de la Hermandad en Castilla la Nueva: modelos tributarios y poderes concejiles (1476-1498)", Chronica Nova, $n^{\circ} 41$ (2015): 275-323.

Otazu, Alfonso de y Díaz de Durana, José Ramón. El espíritu emprendedor de los vascos. Madrid: Sílex, 2008.

Pareja Delgado, María Josefa. Baeza y Úbeda en la Baja Edad Media. Granada: Editorial don Quijote, 1988.

Pulgar, Fernando del. Crónica de los Reyes Católicos. Edición de Juan de Mata Carriazo y Gonzalo Ponto Gijón. Granada: Marcial Pons, 2008.

Quintanilla Raso, María Concepción. "La nobleza". En Orígenes de la Monarquía Hispánica. Propaganda y legitimación (ca. 1400-1520), dirigida por José Manuel Nieto Soria, 73-8. Madrid: Dykinson, 1996.

Quintanilla Raso, María Concepción y Asenjo González, María. "Los hidalgos en la sociedad andaluza a fines de la Edad Media", en Las ciudades andaluzas (siglos XIII-XVI). Actas del VI Coloquio Internacional de Historia Medieval de Andalucía, editado por José Enrique López de Coca Castañer y Ángel Galán Sánchez, 419-433. Málaga: Universidad de Málaga, 1991. 
Rodríguez Sarria, Julieta. "Fisco, poder y distinción social en Sevilla y su tierra en el siglo XV: una propuesta de trabajo". En Poder, fisco y mercado en las ciudades de la Península Ibérica (siglos XIV-XVI), editado por David Carvajal de la Vega, Imanol Vítores Casado y Javier Añibarro Rodríguez. Valladolid: Castilla ediciones, 2016.

Romero Romero, Francisco José. Sevilla y los pedidos de Cortes en el siglo XV. Sevilla: Ayuntamiento de Sevilla, 1997.

Sánchez Benito, José María y Guerrero Navarrete, Yolanda. "El proceso constituyente de la Hermandad General. Los ordenamientos de 1476 a 1478", Anuario de Historia del Derecho Español, no 59 (1989): 633-698.

Sánchez de Arévalo, Rodrigo. "Vergel de príncipes". En Prosistas castellanos del siglo $X V$, editado por Mario Penna. Madrid: Biblioteca de Autores Españoles, Atlas, 1959.

Sánchez Saus, Rafael. "Caracterización de la nobleza medieval en el área onubense". En Huelva en la Edad Media. Reflexiones, aportaciones y nuevas perspectivas veinte años después, editado por Juan Luis Carriazo Rubio y José María Miura Andrades, 37-62. Huelva: Universidad de Huelva, 1998.

- Caballería y linaje en la Sevilla Medieval. Cádiz: Diputación provincial de Sevilla y Universidad de Cádiz, 1989.

Schumpeter, Joseph Alois. "La crisis del Estado fiscal", Revista Española de Control Externo, vol. 2, no 5 (2000): 147-192.

Soria Mesa, Enrique. El cambio inmóvil. Transformaciones y permanencias en una élite de poder (Córdoba, ss. XVI-XIX). Córdoba: Ayuntamiento de Córdoba, 2000.

- La nobleza en la España moderna. Cambio y continuidad. Madrid: Marcial Pons, 2007.

Toral Peñaranda, Enrique, Úbeda, 1442-1510. Jaén: Instituto de Estudios Jienenses, 1975.

Triano Milán, José Manuel. "El arzobispado de Sevilla y el obispado de Cádiz. Imagen de un gran partido fiscal en la recaudación del pedido regio", Historia. Instituciones. Documentos, $\mathrm{n}^{\circ} 40$ (2013): 361-395.

- "De la restauración de la justicia a la lucha contra el infiel. La legitimación de los ingresos fiscales de la Santa Hermandad (1476-1498)", En la España Medieval, vol. 41 (2018): 105-131.

- La llamada del rey y el socorro del reino. Del pedido regio a las contribuciones de la Santa Hermandad (1406-1498). Sevilla: Universidad de Sevilla, 2018.

- “Un nuevo sistema de fiscalidad extraordinaria? La Santa Hermandad de los Reyes Católicos (1476-1498)", Studia Histórica. Historia Medieval, $\mathrm{n}^{\circ}$ 36/2 (2018): 171-197. 
Triano Milán, José Manuel y Rodríguez Sarria, Julieta. “Algunas consideraciones en torno a la concesión, recaudación y gasto del pedido regio en Sevilla y su tierra en 1454", En la España Medieval, vol. 38 (2015): 329-352.

Val Valdivieso, María Isabel del. "Oligarquía versus común. Consecuencias sociopolíticas del triunfo del regimiento en las sociedades castellanas", Medievalismo, $\mathrm{n}^{\circ} 4$ (1994): 41-58. 